\title{
DARI ANONIM KEMBALI KE ANONIM
}

\author{
Itsna Hadi Saptiawan \\ Dinas Pendidikan dan Kebudayaan Provinsi NTB \\ Posel: itsnahs@gmail.com
}

\begin{abstract}
The context of current mass communication in Indonesia, especially on social media, shows news constellations that lead to hoax war and the spread of fake accounts (bots). This study aims to normatively understand the historical role of literature behind the emergence of these anonymous characteristics and the latest patterns presented in the public space. The internet as a communication laboratory is the main subject of content analysis. The results show that social media has the potential to expand and disseminate communication that is more intense and massive when compared to other internet mediums.
\end{abstract}

Keywords: anonymous; hoaxes; communication.

\begin{abstract}
Abstrak
Konteks komunikasi massa terkini di Indonesia khususnya di media sosial menunjukkan konstelasi berita yang mengarah kepada perang hoaks serta bertebarannya akun-akun palsu (bot). Penelitian ini bertujuan untuk memahami secara normatif peran historis teks yang melatarbelakangi munculnya karakteristik anonim ini berikut pola-pola terkini yang disajikan olehnya di ruang publik. Internet sebagai laboratorium komunikasi merupakan subjek utama content analysis. Hasil penelitian menunjukkan bahwa media sosial memiliki potensi perluasan dan penyebaran komunikasi yang lebih intens dan massif bila dibandingkan dengan medium internet lainnya.
\end{abstract}

Kata kunci: anonym; hoaks; komunikasi.

\section{PENDAHULUAN}

Konon, keperiadaan kita dalam sejarah bermula dari peninggalan tradisi tulis yang terdapat pada berbagai kebudayaan di masa lampau. Warisan berupa benda-benda fisik seperti prasasti maupun naskah karya sastra menjadi dua buah penanda kehadiran manusia di dalam rentang kronologi dunia. Ekspresi verbal para nenek moyang kita ini termaktub sebagai piagam, maklumat, surat keputusan, undang-undang, legenda, atau bahkan dongeng. Keberadaan tulisan di dalam sejarah telah melintasi batasan yang kabur perihal pemilik sah kebudayaan dunia yang sebelumnya hanya direka-reka berdasarkan peninggalan arkeologis nontulis seperti gambar-gambar di gua, peralatan berburu dan meramu, atau sarkofagus dan menhir di era megalitik.

Meskipun demikian, kehadiran tulisan pada berbagai peradaban dunia tidak serta merta menghilangkan sepenuhnya keraguan akan identitas pemiliknya mengingat tulisan pada masa itu cenderung dianggap sebagai milik bersama, jika tidak merupakan kreasi monumental penguasa yang sedang memerintah. Terutama sekali pada karya sastra, anggapan bahwa teks di dalamnya merupakan pengetahuan bersama atau sebagai konvensi di masyarakat mendorong sang pengarang untuk menghadirkan diri sebagai sosok anonim pada karya yang dihasilkannya.

Di Nusantara, sifat penulisan anonim ini berlanjut hingga era akhir ketika hikayat dan jenis sastra Melayu Lama lainnya masih menjadi milik bersama suatu masyarakat. Para pengarang yang lazimnya hidup di kalangan istana, menghadirkan diri mereka sebagai representasi kerajaan pada karya yang ditulis. Sehingga, bukan suatu keanehan jika teks pada era ini dianggap bersifat istanasentris karena kandungannya yang lebih banyak berkutat perihal kehidupan istana, termasuk 
dongeng, legenda, mite dan sejenisnya yang berada dalam kerangka mendudukkan istana sebagai kutub sakral kehidupan bermasyarakat.

Meskipun demikian, bisa jadi anonimitas pada era ini tidak melulu disebabkan karena teks yang ditulis oleh pengarang merupakan konvensi di dalam masyarakat. Mari membayangkan bahwa pengarang pada masa itu mencoba untuk menulis dengan perspektif yang berbeda dengan kehendak penguasa. Masalahnya adalah sang pengarang tidak dapat memutus rantai budaya antara teks yang ia hasilkan dengan aktualisasinya dalam tradisi oral. Seringkali, hikayat dibacakan kepada khalayak sebagai wujud pengagungan terhadap raja, sebagai pelipur lara, termasuk juga bahan pengajaran bagi masyarakat. Jika tulisan nonkanonik yang berupaya dihasilkan oleh pengarang berbeda dengan kepentingan kerajaan, bisa saja ia kemudian memilih untuk menyimpan bagi dirinya sendiri atau dibagikan kepada kalangan terbatas yang dipercayainya. Ini dapat menjadi salah satu kemungkinan lain yang mendorong pada pilihan anonimitas.

Cerita yang berkembang di luar alur yang dikehendaki oleh penguasa, dimungkinkan muncul dalam beberapa kondisi semisal era berlangsungnya peristiwa tersebut telah lewat. Kemudian yang kedua, penulis peristiwa itu adalah pihak lain di luar kewenangan penguasa atau pihak yang memiliki hegemoni lebih kuat dari penguasa dimaksud. Hal semacam ini dapat kita temukan misalnya pada tragedi pembantaian terhadap ribuan ulama dan santri yang diperintahkan oleh Amangkurat I. Cerita yang terdapat dalam Babad Tanab Jawi ini tentu saja tidak beredar di masa-masa terjadinya peristiwa bersangkutan. Ia dipublikasikan jauh setelah Amangkurat I tewas lalu disadur oleh Graff dan Meinsma yang notabene adalah orang Belanda.

Dikaitkan dengan konteks komunikasi massa, karya sastra berada pada jalur menyampaikan atau memberitakan berbagai peristiwa kepada masyarakat. Saat diceritakan atau dibaca, teks-teks yang terkandung di dalamnya merupakan pengejawantahan interaksi antara pengarang dengan para pendengar atau pembacanya. Bedanya dengan model komunikasi massa terkini, interaksi dalam konteks ini masih bersifat satu arah, pembaca menafsirkan sendiri wacana yang disajikan. Kecuali ketika teks di dalam karya sastra itu disampaikan di hadapan orang banyak sebagai materi pembelajaran dan sebagainya, interaksi yang terjalin dimungkinkan dapat berlangsung secara imbal balik. Karakteristiknya menunjukkan bahwa karya sastra mengandung pesan-pesan yang dikomunikasikan melalui media massa pada sejumlah besar orang. Media massa yang dimaksud dalam hal ini secara kronologis mengacu pada khalayak ramai yang kompleksitasnya kini kita kenali dalam bentuk interaksi langsung maupun virtual (internet).

\section{METODE PENELITIAN}

Penelitian ini menggunakan metode analisis isi kualitatif (analisis wacana). Metode ini digunakan mengingat data penelitian merupakan teks komunikasi yang dinamis dan berkembang. Opsi penyuntingan yang lazim tersedia pada berbagai media sosial mensyaratkan penggunaan teknik pengambilan sampel yang dapat mencatat aktivitas komunikasi yang paling sesuai dengan tujuan penelitian. Data dalam penelitian ini meliputi nama akun, pilihan bahasa komunikasi, arah komunikasi, termasuk medium-medium komunikasi yang lazim digunakan seperti mailing list, website, dan portal berita. 


\section{HASIL DAN PEMBAHASAN}

Anonim berasal dari bahasa Yunani anōnymos ( $a_{-}+$onyma) yang berarti tanpa nama atau identitas, atau tidak dikenali ( ${ }^{1}$. Istilah ini pertama kali merujuk pada konteks kepengarangan atau asal usul yang tidak diketahui. Di internet, pengertian anonim terkini mengarah kepada keberadaan suatu entitas (individu/kelompok) yang secara serampangan atau terorganisir menampilkan dirinya secara tidak langsung (undirect profiling) baik melalui akun tanpa nama, akun palsu, maupun sebagai kontrol tak terlihat atas berbagai lintas komunikasi dunia maya.

Perihal anonimitas dalam interaksi komunikasi, internet dewasa ini menunjukkan model yang mengarah kepada pengerubungan ide yang di dalamnya satu wacana dihakimi oleh ratusan, ribuan, atau bahkan jutaan orang. Polanya adalah dengan memunculkan satu gagasan/berita/dan lain-lain yang disajikan secara daring untuk kemudian ditanggapi verbal maupun simbolik oleh para netizen. Yang terjadi berikutnya adalah interaksi menjadi tidak terbatas. Arah interaksi dapat melebihi jumlah tanggapan yang masuk karena komentar pun dapat melahirkan cabang-cabang komentar yang lain.

Wadah yang menampung interaksi di internet ini terbagi berdasarkan layanan yang dipakai oleh para penggunanya. Umumnya, interaksi antara para pengguna internet dengan suatu postingan terdapat pada layanan seperti portal berita daring, layanan percakapan, mailing list, blog, hingga yang terpopuler saat ini, media sosial seperti Facebook, Twitter, Instagram, maupun Youtube. Khususnya di media sosial, interaksi berlangsung secara terbuka, sporadis atau bertubi-tubi, dan melibatkan sejumlah besar massa dengan ide yang belum tentu sama dengan postingan yang ada.

Multitipe interaksi ini dapat sejalan atau bahkan menyimpang sama sekali dari ide pokok wacana. Penyebabnya, akan ada empat pihak yang mengajukan pandangan terhadap ide tersebut yakni yang pro, yang kontra, yang memilih bersifat netral, serta yang menanggapi pada subjek yang sama sekali berlainan dengan pokok permasalahan. Perbedaan-perbedaan pandangan atas suatu ide pokok ini selanjutnya melahirkan friksi-friksi yang mendorong pihak yang bertentangan saling berbalas pemikiran. Hanya saja, terkadang dispersi pemikiran itu tidak lagi murni berdiri pada koridor awal pembicaraan. Ia berkembang dari persetujuan, simpati, penolakan, hingga caci maki atas tawaran ide pemilik postingan. Pada tingkatan ini, model komunikasi menjadi kompleks tidak hanya karena banyaknya jumlah pengguna internet yang berkomentar, atau karena keberadaan empat kutub yang berhadap-hadapan, akan tetapi karena para pihak yang berkomentar berubah wujud menjadi anonim dalam sirkumstans itu.

Seperti apakah anonimitas itu? Sejalan dengan pandangan Juwono dkk. (2010) anonim merupakan suatu sifat yang menunjuk pada ketidakjelasan/ketidakpastian identitas seseorang/suatu pihak. Hirarki anonimitas terbagi menjadi true anonym (anonim penuh) dan pseudo-anonym (anonim semu). Anonim penuh adalah anonimitas yang sulit dilacak karena pelaku secara secara kebetulan atau memang sengaja menyembunyikan identitas dirinya agar menjadi misteri bagi orang lain. Contoh anonim jenis ini banyak ditemukan pada situs blog maupun portal berita daring. Lazimnya, kemunculan anonim penuh dalam kasus ini dikarenakan halaman situs memang menyediakan format untuk memasukkan komentar yang para calon komentatornya mempunyai opsi untuk menampilkan identitas melalui akun internet yang dimilikinya atau berkomentar sebagai sosok anonim sama sekali.

Dalam penyajian berita, sifat anonim mulai hadir dari pihak pertama yang menyajikan wacana hingga pihak berikutnya yang menanggapi wacana bersangkutan. Anonimitas penyajian

\footnotetext{
${ }^{1}$ https://www.merriam-webster.com/dictionary/anonymous
} 
wacana berkaitan erat dengan "kategori subjek" yang menghadirkan wacana tersebut, sebagai sumber asli berita atau hanya sebagai pihak sekunder atau pihak kesekian yang mendengar berita kemudian membagikannya. Anonimitas itu terjadi juga karena pihak penyampai berita tidak menyebut diri sebagai pribadi tertentu, tetapi sebagai suatu institusi/lembaga.

Yang terburuk adalah ketika penyampai maupun penanggap berita keduanya hadir dengan menggunakan akun-akun palsu. Kondisi anonim penuh ini memiliki daya bentur yang lebih berat karena pihak penggunanya tidak menanggung implikasi moral maupun sosial seberat pemakaian akun asli. Para pihak pengguna akun-akun palsu tidak memiliki kekhawatiran untuk "diserang" seperti yang terjadi pada pengguna akun asli. Pertama karena jati aslinya terlindung di balik akun tersebut, yang kemudian pada tahap berikutnya memberikan keamanan dan kenyamanan bagi penggunanya untuk menyampaikan gagasan sekehendak hati.

Pada saat kondisi seperti ini berlangsung, anonimitas menjadi tameng propaganda yang mumpuni. Di suatu momen tertentu, anonimitas ini menjadi faktor yang menghadirkan stabilitas bagi lingkungan sekitarnya dengan wacana-wacana yang berupaya mendorong pada konsensus di dalam masyarakat. Sebaliknya, dalam momen yang bersamaan anonimitas dapat pula menjadi alat untuk memecah belah, atau seperti yang sedang dipopulerkan oleh rezim sekarang sebagai ancaman terhadap kebhinnekaan di Indonesia.

Menariknya, anonimitas di internet khususnya di media sosial tidak hanya berbentuk ketiadaan nama semata. Anonimitas yang kedua yakni pseudo-anonym merujuk pada perkembangan aplikasi teknologi yang memungkinkan pengguna internet atau media sosial untuk menggunakan gambar/foto sebagai penanda identitas. Dalam konteks ini, ketiadaan foto atau penggunaan foto yang tidak memiliki korelasi sama sekali dengan identitas asli pengguna internet merupakan sebuah anonimitas tersendiri. Bisa saja nama yang tercantum adalah nama asli, tetapi menjadi sulit untuk diakui kebenarannya karena dibutuhkan pembanding yang akurat seperti foto dan video. Bisa juga foto yang dipajang sebagai foto profil adalah foto asli, namun masalahnya tidak semua orang dapat mengkonfirmasi bahwa foto profil yang ditampilkan tersebut sesuai dengan nama pemilik akun.

Reproduksi dalam kasus nama-nama alay misalnya, merupakan satu bentuk lain anonimitas semu yang mengaburkan jati diri asli pengguna internet bersangkutan. Dalam studinya tentang proses pembentukan dan implikasi bahasa alay terhadap perkembangan Bahasa Indonesia, Kelana (2011) mengemukakan bahwa fungsi penggunaan bahasa alay adalah sebagai fungsi gaul, fungsi identitas (diri dan kelompok), sebagai filter password, dan sebagai penambah kesan lucu dan unik. Pada kasus ini, seorang pengguna internet memakai nama unik dan lucu pada akun yang dimilikinya. Alih-alih mempermudah, nama alay yang disematkan pada profil akun itu malah kerap menyulitkan bagi sebagian orang yang dikategorikan atau merasa diri berada di luar komunitas pengguna nama alay tersebut.

Bentuk anonimitas semu lainnya di samping ketiga contoh di atas yakni penggunaan bahasa yang berbeda di dalam komentar dengan bahasa yang digunakan pada suatu postingan. Bahasa daerah dan bahasa asing dapat menjadi tersangka dalam hal ini. Penyebabnya ialah bahwa suatu postingan biasanya diplot untuk mendapatkan tanggapan/komentar dalam bahasa yang dapat dipahami baik oleh pihak yang memposting maupun pihak yang berkomentar terhadap isi postingan. Ketika komentar yang muncul menggunakan bahasa daerah atau bahasa asing yang tidak dipahami oleh para komunikan, komentar tersebut berdiri sebagai ekspresi yang absurd. Anonimitasnya terjadi karena muatan ekspresi di dalam komentar tersebut sama sekali tidak dipahami oleh komunikan lainnya, entah itu gembira, setuju, sedih, menghardik, atau lainnya. 
Lebih-lebih lagi jika pemberi komentar tidak menambahkan penanda ekspresi semisal emoticon dan sejenisnya, jadilah komentar itu terasing dari konteks pembicaraan antara isi postingan dengan tanggapan terhadapnya.

Pada tahapan ini, jika kita merunut pada kondisi terkini di Indonesia, ditemukan banyak bentuk anonimitas serupa dengan berbagai macam konten di dalamnya. Pada laman blog maupun portal berita, pihak yang hendak berkomentar kini diberikan opsi untuk menampilkan diri sebagai akun anonim atau akun bernama sesuai dengan akun aktif yang dimiliki (Google+, Facebook, Twitter, Instagram, dan sebagainya). Interface (antarmuka) pada laman internet semacam ini tentu saja dapat mengurangi potensi penggunaan akun anonim meskipun tidak menjadi jaminan bahwa akun aktif yang digunakan memang benar-benar akun asli yang dimiliki oleh pemberi komentar.

Di media sosial, keharusan memiliki akun aktif tidak serta merta mendorong probabilitas untuk anonim menjadi lebih rendah. Jika pada blog, portal berita, atau situs web umumnya, pengguna memiliki pilihan untuk berkomentar sebagai anonim atau berjati diri, pada media sosial para pihak yang terlibat dalam suatu pembicaraan memang harus memiliki akun aplikasi bersangkutan untuk dapat memposting atau berkomentar. Implikasinya, keterbukaan jati diri di dalam layanan internet jenis ini seharusnya lebih tinggi. Meskipun demikian, tidak lantas dapat dinyatakan bahwa anonimitas para penggunanya berkurang. Dilansir oleh Kompas.com, Facebook pada laporan kuartal empat 2013 mengungkapkan bahwa 5,5 hingga 11,2 persen akun Facebook ternyata palsu. Akun-akun tersebut jumlahnya mencapai 67,65 juta hingga bulan Desember 2013. Menurut perkiraan persentase tertinggi Facebook, angka tersebut bisa melonjak menjadi 137,76 juta akun. BBC online dalam laporannya pada 24 Januari 2017 mengungkapkan bahwa terdapat sejumlah besar jaringan akun palsu di Twitter. Jaringan dari lebih 350.000 bot (akun palsu) ini ditemukan berdasarkan karakteristiknya yang mirip satu sama lain seperti tweet yang berasal dari tempat yang tidak ada kehidupan, pesan yang diposting dari ponsel Windows, serta kutipan yang hampir secara eksklusif diambil dari novel novel Star Wars. Para peneliti dari Inggris secara tidak sengaja menemukan jaringan akun palsu tersebut ketika menyelidiki cara pengguna menggunakan twitter. Beberapa akun telah digunakan untuk memalsukan jumlah follower, mengirim spam dan mendorong ketertarikan pengguna lain untuk terlibat dalam trending topics.

Dengan demikian, perbandingan antara laman blog, portal berita, dan situs web umumnya dengan media sosial dalam hal kemungkinan penggunaan akun anonim tampaknya tetap dimenangkan oleh media sosial. Faktornya sangat jelas. Pertama, jumlah pengguna media sosial jauh lebih banyak daripada pengguna jenis layanan internet yang pertama. Karena memiliki jumlah pengguna yang lebih banyak, lalu lintas interaksi antarpengguna di media sosial jauh lebih padat daripada jenis layanan yang pertama. Ketiga, feedback (umpan balik) terkait suatu postingan pada media sosial lebih cepat sehingga peluang untuk terlibat atau mendistraksi pokok pembicaraan menjadi lebih besar. Keempat, media sosial menyediakan ruang legal yang bebas untuk menyampaikan konten apapun yang berbeda dengan isu-isu aktual di masyarakat. Kelima, validitas atau kesahihan berita bukanlah syarat utama suatu isu dikemukakan di media sosial. Sepanjang berita tersebut dibaca dan ditanggapi oleh banyak pengguna untuk kemudian dibagikan secara berulang-ulang, validitasnya diperoleh berdasarkan pembenaran massal melalui proses reduplikasi berita. Keenam, hoaks. Laman blog, portal berita, maupun situs web umumnya hanya dikunjungi oleh sedikit pengguna internet. Di samping itu, proses pembuatan domain internet tidaklah secepat pembuatan akun media sosial. Artinya, potensi penyebaran 
berita bohong pada jenis layanan internet yang pertama kalah efektif dibandingkan dengan penyebarannya pada media sosial. Dengan mempertimbangkan efektivitasnya ini, potensi pengguna anonim baik dalam bentuk ketiadaan nama maupun akun-akun palsu menjadi lebih besar.

Lantas, untuk apa harus anonim? Kemajuan teknologi telah menawarkan "lahan terbuka hijau" yang luas bagi siapapun untuk dapat menunjukkan dirinya pada dunia. Internet beserta segala fiturnya merupakan taman bagi yang hendak berekreasi, ruang kantor bagi yang hendak bekerja, atau bahkan rumah ibadah bagi yang menyeru pada pesan-pesan kebaikan di dalamnya. Jika memang ia dibuat untuk menunjukkan eksistensi diri, mengapa pelakunya justru memilih untuk menjadi anonim? Tidakkah dalam era narcissus sekarang ini, menunjukkan diri justru merupakan suatu tren, dalam bentuk swafoto dan sejenisnya?

Kita tidak ingin sekedar menyatakan bahwa setiap hal di dunia berpasangan, yang baik berpasangan dengan yang buruk, yang bagus dengan yang jelek, atau yang ekstrovert berdampingan dengan yang introvert. Yang ingin diketahui ialah motivasi logis memilih menjadi anonim. Sehingga, terlalu sederhana kalau kemudian menyimpulkan bahwa pilihan menjadi anonim di internet dikarenakan pelakunya adalah sosok yang tertutup, introvert, bla bla bla. Tidak tertutup kemungkinan pilihan menjadi anonim justru dilakukan oleh orang dengan karakteristik sebaliknya. Namun apa motifnya?

Penulis teringat pada sosok pahlawan super semacam Superman atau Spiderman, para pahlawan yang menyembunyikan diri dalam rutinitasnya sebagai orang biasa. Di satu sisi mereka tampil perkasa menampakkan diri sebagai tokoh pembela kebenaran, sebagai pria super, sebagai laki-laki dengan jaring laba-laba. Namun di sisi lain, eksistensinya sebagai tokoh populer justru menjadikan mereka berbeda. Mungkin tidak secara fisik, lebih tepatnya secara sosial dengan manusia di sekitarnya. Oleh karena itulah mereka melaksanakan laku menyaru (menyamar) pada lingkungan sosialnya. Mereka sama dengan orang lain, tetapi memiliki kekuatan super untuk melakukan tugas yang mustahil dikerjakan oleh manusia rata-rata. Maka secara tidak langsung rutinitas kehidupan mereka menjadi terbalik, mereka menjadi anonim dalam konteks kehidupan nyata namun menjadi eksis dalam peristiwa insidental yang sporadis. Nah, bukankah anonimitas di internet juga kadang demikian?

Menyamar di dunia maya bisa jadi merupakan suatu modus untuk meraih stabilitas yang bertahan lama, dalam hal ini maksudnya tentu saja agar pelakunya dapat dengan langgeng melaksanakan rencana-rencana yang sudah diagendakannya. Dengan menjadi anonim maka ia bermetamorfosis dari jati dirinya yang kompleks menjadi pribadi lain dengan karakter khusus yang dibenamkan pada pola pikir dan perilakunya. Karena dengan menjadi anonim stabilitas pada kecenderungan terhadap suatu perilaku terjaga, maka pelakunya berusaha untuk tidak menghindarkan diri dari konflik. Ia aman karena identitas aslinya terlindungi oleh sekian banyak tameng luar yang menutupinya.

\section{Anonimitas yang Terlembagakan}

Kim LaCapria pada laman snopes.com (2016) menawarkan enam cara cepat untuk mengenali berita bohong. Pertama ialah dengan menelusuri tanggal kemunculan berita melalui jejaknya pada tautan yang dibagikan. Bisa jadi tautan yang dibagikan merupakan konten yang telah diperbaharui dengan tujuan menghasilkan like sebanyak-banyaknya. Apakah waktu berita tersebut sesuai dengan kondisi terkini? Atau jangan-jangan beritanya telah kadaluarsa namun baru diposting beberapa tahun setelahnya. Kedua, cara berikutnya untuk mendorong penyebaran 
berita bohong ialah dengan memanfaatkan efek dari beberapa situs populer yang secara serentak menayangkan berita viral yang sumber utamanya tidak melalui pemeriksaan keaslian berita. Artinya, tidak ada proses cek dan ricek baik terhadap isi maupun sumber berita. Ketiga, dengan mengkonfirmasi daftar situs yang dikenal sebagai pemasok berita bohong. Artikel-artikel yang diberitakan oleh situs-situs tersebut kerap kali meraih respon yang signifikan di media sosial, terutama pada isu-isu nasional yang menonjol. Snopes.com diklaim memiliki unit yang bertugas melacak dan menyusun daftar hitam situs dengan kategori tersebut.

Keempat, the deception is in the details. Salah satu teknik yang kerap digunakan oleh situs berita bohong ialah dengan mendompleng nama situs berita populer sehingga berita yang mereka sajikan seolah-olah benar dan dengan cepat menimbulkan skepstisime di masyarakat. Muslihat ini terungkap setelah memperhatikan domain situs yang ternyata berbeda dengan situs aslinya. Misalnya antara washingtonpost.com dengan washingtonpost.com.co atau antara situs berita washingtonpost.com dengan washingtonpost.com.info. Kelima, manipulasi foto. Cara berikutnya yang kerap digunakan oleh suatu akun atau situs penyebar hoaks ternyata melibatkan penggunaan manipulasi foto, termasuk deskripsi terhadap suatu foto yang konteks aslinya berbeda dengan yang diberitakan dapat menjadi contohnya. Indonesia akhir-akhir ini sedang melalui masa tersebut. Masyarakat yang sedang memasuki era gadget, saat tahap pengenalan dasar fotografi tidak dipahami selain opsi otomatis pada start up bawaan gadget masing-masing membuat kurangnya pengetahuan dan ketelitian terhadap keaslian suatu foto. Aslikah foto kerangka manusia raksasa yang diklaim sebagai jasad Nabi Adam itu dan dibagikan sebagai wallpaper sejak era 2000-an? Atau foto Ahok yang hadir dalam kegiatan suatu parpol padahal dirinya sedang ditahan di Mako Brimob? Atau beberapa foto tragedi Rohingya yang bagi sebagian kalangan diklaim sebagai foto palsu? Keenam, peristiwa tersebut terjadi di belahan dunia mana? Rusia dan China seringkali digunakan sebagai latar untuk berita yang sulit dikonfirmasi kebenarannya. Lokasi yang dipublikasikan ialah berupa nama-nama aneh atau daerah-daerah terpencil yang karena kendala bahasa atau budaya sulit untuk dilacak. Termasuk konten berita yang disajikan terkesan bombastis seperti suami yang dikebiri setelah ketahuan berselingkuh, seorang suami yang menuntut istrinya karena melahirkan anak yang buruk rupa, hingga rumor tentang seorang penambang yang berhasil diselamatkan setelah bertahan selama 17 tahun di bawah tanah. Di akhir artikelnya, LaCapria menyimpulkan bahwa omong kosong jika tautan-tautan yang kerap dibagikan di internet tidak mengikuti pola seperti dijelaskan di atas. Kredibilitas berita yang ditampilkan, imbasnya tidak lebih seperti mencari sensasi untuk meningkatkan jumlah kunjungan pada situs yang dikelola.

Di samping LaCapria, Kelsey Weekman (AOL.com) juga berbagi tips menghindari hoaks. Satu, dengan membandingkan berbagai sumber berita, termasuk memeriksa kredibilitas sumber berita semisal keterkaitannya dengan partai politik atau lembaga tertentu. Dua, dengan memanfaatkan keberadaan situs pemeriksa keabsahan berita seperti snopes.com atau factcheck.org yang orientasinya ialah membangun basis data terkait situs-situs yang kerap menyebarkan berita bohong. Tiga, mencermati situsnya lebih dekat. Jika situsnya memiliki tampilan dasar seperti blog pribadi, kita harus memeriksa lebih dalam dengan memastikan bahwa situsnya telah lama dibuat dan memiliki banyak postingan sebelumnya. Empat, memeriksa tanggal penayangan berita. Situs-situs penyebar hoaks kerap mempublikasikan ulang berita lama yang bertujuan memancing ketertarikan pengguna internet untuk mengunjungi situsnya. Lima, jika tajuk beritanya terkesan bombastis, bacalah artikelnya dengan cermat. Terkadang berita yang sensasional lebih cepat menjadi tren daripada berita yang biasa-biasa saja. Enam, situs lebih 
penting daripada orang yang berbagi berita. Kita mungkin akan melihat seorang figur publik yang membagikan sebuah berita yang ternyata hoaks. Alhasil, cermati dulu sumber beritanya, bukan orang yang membagikannya. Tujuh, gunakan esktensi/add-ons pada peramban anda untuk memverifikasi berita. Terakhir, mengecek daftar situs yang terindikasi menyebarkan berita bohong seperti yang telah dipublikasikan oleh Melissa Zimdars².

Menyimak tips dari kedua pengamat ini, pemerintah melalui Kemenkominfo atau lembaga berwenang lainnya sudah sewajarnya mengadaptasi model pengawasan komunikasi dengan berpedoman pada salah satu atau keduanya. Dengan demikian, pemerintah tidak terkesan selalu uring-uringan setiap ada pemberitaan yang berbeda atau yang bernada menentang kebijakan pemerintah lantas memvonis situs-situs tersebut sebagai penyebar berita hoaks. Ini di samping akan membantu kerja pengawasan dari Kemenkominfo, juga untuk menghindarkan lembaga tersebut dari tuntutan para pemilik situs yang menjadi korban salah blokir.

Ini mengingatkan kembali pada pernyataan Rocky Gerung, dosen di Departemen Filsafat Fakultas Ilmu Budaya Universitas Indonesia dalam acara Indonesia Lawyer Club (TVOne, 17/1/2017) yang mengkritik keras cara pemerintah dalam menangani hoaks. Menurutnya, seperti dilansir Republika (18/03/2017), rezim saat ini semacam ingin mengendalikan kebenaran sesuai dengan standarnya. Ia mencurigai ada kebohongan yang disembunyikan dalam upaya keras pemerintah melawan hoaks. Justru menurut Rocky Gerung, pembuat hoaks terbaik adalah penguasa. Hal ini karena penguasa memiliki seluruh peralatan untuk berbohong: intelejen, data statistik, maupun media massa. Dari pernyataan ini, Rocky Gerung seolah ingin mengungkapkan bahwa penguasa juga adalah pihak yang paling mungkin untuk menyebarkan hoaks dalam rangka penciptaan isu atau sebagai sanggahan terhadap isu yang telah beredar sebelumnya. Oleh karena itu harus ada cara yang lebih baik dalam menangani penyebaran berita, dan salah satu yang moderat ialah seperti dikemukakan oleh kedua pengamat di atas, yakni dengan terlebih dahulu mencerdaskan pembacanya.

\section{SIMPULAN}

Anonimitas di dunia komunikasi pada prinsipnya menawarkan stabilitas rasa aman bagi para penggunanya. Meskipun demikian, fase aman ini pada konteks komunikasi kontemporer telah dimanfaatkan sebagai tameng guna melakukan penyebaran konten-konten negatif yang meresahkan di ruang publik. Teks dalam kerangka ini berkembang dari berita rahasia (sensitif) menjadi konsumsi publik. Saat kelembagaan anonimitas dilindungi oleh negara, ia berubah dari sekadar pemindai menjadi pengawas yang menghadirkan teror bagi sebagian masyarakatnya. Perihal perkembangan karakteristik anonim, media sosial memiliki jangkauan kemampuan yang lebih kuat dan lebih luas bila dibandingkan dengan media komunikasi lainnya sebab dapat dikendalikan langsung oleh individu yang terikat secara emosional pada isu-isu pokok yang sedang bergulir.

\section{DAFTAR PUSTAKA}

BBC.com. 24 Januari2017. "Massive Networks of Fake Accounts Found On Twitter". Juwono, dkk. 2010. "Sifat Anonym di dalam Dunia Maya (Cyber Space)". Bahan Presentasi. Siskom.

\footnotetext{
${ }^{2}$ https://docs.google.com/document/d/10eA5-mCZLSS4MQY5QGb5ewC3VAL6pLkT53V_81ZyitM/preview
} 
Kelana, Natalia Diah. 2011. Fenomena "Bahasa" Alay: Proses Pembentukan dan Implikasinya terhadap Perkembangan Bahasa Indonesia. (Skripsi). Semarang: Universitas Diponegoro.

Kelsey Weekman. 14 Nopember 2016, pada AOL.com. "How to Avoid Fake News Articles". Kim LaCapria. 21 Januari 2016, pada Snopes.com. "6 Quick Ways to Spot Fake News".

https://docs.google.com/document/d/10eA5-mCZLSS4MQY5QGb5ewC3VAL6pLkT53 V 81 ZyitM/preview

https://www.merriam-webster.com/dictionary/anonymous

Reska K. Nestanto. 8 Februari 2014, pada Kompas.com. "Facebook Beberkan Jumlah Akun Palsu dan Kelakuannya".

https://jalantikus.com/tips/sosok-asli-muslim-cyber-army/ 